\title{
POPPIES AND GOLD: OPIUM AND LAW-MAKING ON THE WITWATERSRAND, I904-IO*
}

\section{Thembisa Waetjen}

University of Johannesburg

\begin{abstract}
In the wake of the South African war, the indenture and transport of over 63,000 Chinese men to gold mines in the Transvaal sparked a rush to supply smoking opium to a literally captive market. Embroiled in a growing political economy of mass intoxication, state lawmakers shifted official policy from prohibition to provision. Their innovation of an industrial drug maintenance bureaucracy, developed on behalf of mining capital in alliance with organized pharmacy and medicine, ran counter to local trends of policy reform and represents a unique episode for broader histories of modern narcotics regulation. This article considers the significance of this case and chronicles the contradictory interests and ideologies that informed political scrambles over legitimate opium uses, users, and profiteers. It shows how the state maintained its provision policy, for as long as it proved expedient, against varied and mounting public pressures - local and international - for renewed drug suppression. The argument here is that the state managed an epidemic of addiction on the Rand as an extraordinary problem of demography. It achieved this both through redefining smoking opium from intoxicant to mine medicine and through the legal construction of a 'special biochemical zone', which corresponded with the exceptional status and spatial segregation of a despised alien labour force.
\end{abstract}

\section{Key Words}

South Africa, law, labour, migration, medicine, race.

In the first decade of the twentieth century, the opium trade was the focus of struggles over the regulatory orders of empires and self-ruling states. Remote from the principal Asian theatres of these conflicts, the trade yet made a brief but influential appearance in the Transvaal. ${ }^{\mathrm{I}}$ Between I904-I0, transport and confinement of 63,695 men from northeastern China, recruited and indentured as unskilled gold mining labour, stimulated a

* My thanks to Julie Parle and her Pharmaceutical Modernities initiative for giving life to this research. I am grateful to Gerhard Maré for close reading and discussions, and to the editors and three anonymous Journal of African History referees for their generous assistance towards the final version. I presented this article at the Wits Interdisciplinary Seminar in the Humanities and benefited from the comments and suggestions of, among others, Prinisha Badassy, Keith Breckenridge, Catherine Burns, Nafisa Essop Sheik, Andrew McDonald, Hlonipha Mokoena, and Stephen Sparks. Author's email: thembisa@gmail.com

I T. Waetjen, 'The rise and fall of the opium trade in the Transvaal, I904-I910', Journal of Southern African Studies (forthcoming). 
rush to supply smoking opium on the Witwatersrand. ${ }^{2}$ In the very moment when a global anti-opium consensus was beginning to take root, a colonial government at the southern end of Africa was deeply implicated in growing a political economy of mass intoxication.

Lawmakers shifted policy from prohibition to provision to accommodate the Chamber of Mines, which, in alliance with the Pharmacy Board and Medical Council, lobbied for an authorized system of drug maintenance. The mining industry was seeking more directly to manage the metabolic chemistry of labouring bodies and to bring a thriving informal drug trade in the compounds under its own domain of control. Medical and pharmacy professionals, newly organized and with advisory powers to the state, looked to secure the authority of their expertise and exclusionary entitlements of practice, and to monopolize sales. The Opium Trade Regulation Law of 1906 initiated a bureaucratic regime of prescriptions and permits that medicalized smoking opium and legitimated the monthly purchase of two pounds (2lbs) of the substance in its raw form for those diagnosed with a 'confirmed habit'. A sequence of law-making created conditions in which opium commerce and rates of chemical dependency grew rapidly among indentured migrants on the Rand, provoking one critic to observe that the government, having imported labourers from China, would be returning a population of addicts. ${ }^{3}$

The use of law to manage an exogenous, psychoactive substance in relation to an unfree, alien, and labouring population was exercised by other Anglo-Saxonist settler nations notably Australia, Canada, and the United States, all of which similarly depended upon Chinese migrant labour. ${ }^{4}$ However, the Witwatersrand system of industrial opium provision to workers represents a unique episode in histories of modern narcotics regulation. A significant feature of this case lies in the confluence of two models and institutional machineries of drug regulation - medical and penal - that in other contexts were competitively positioned or precariously aligned. ${ }^{5}$ Their convergence on the Witwatersrand, as I will show, emerged within the peculiarities of racial state-formation in South Africa and

2 On Chinese indenture and the Transvaal state, see P. Richardson, Chinese Mine Labour in the Transvaal (London, I982); S. Marks and S. Trapido, 'Lord Milner and the South African state', History Workshop Journal, 8 (I979), 65-6; M.Z. Nkhosi, 'American mining engineers and the labor structure in the South African gold mines', African Journal of Political Economy, I:2 (I987), 66-7; J. Higginson, 'Privileging the machines: American engineers, indentured Chinese and white workers in South Africa's deep-level gold mines, I902-1907', International Review of Social History, 52 (2007), I3-16.

3 Cape Town Archive Repository (KAB) MOH 322, 'Opium on the mines of the Witwatersrand', Copy of Report/Letter from G. Baldwin to Magistrate EHMT Baines, Esq. I May I907.

4 D. Manderson, 'Symbolism and racism in drug history and policy', Drug and Alcohol Review, I8:2 (I999), I79-86; N. Boyd, 'The origins of Canadian narcotics legislation: the process of criminalization in historical context', Dalhousie Law Journal, 8 (I984), I02-36, esp. II4-I8; D. Courtwright, Dark Paradise: A History of Opiate Addiction in America (Cambridge, 200I), 77-8I; T. A. Hickman, 'Drugs and race in American culture: orientalism in the turn-of-the-century discourse of narcotic addiction', American Studies, 4I (spring 2000), 7I-9I.

5 S. Anderson and V. Berridge, 'Opium in twentieth-century Britain: pharmacists, regulation and the people', Addiction, 95:I (2000), 27-30; V. Berridge, 'Drugs and social policy: the establishment of drug control in Britain, I900-30', British Journal of Addiction, 79 (I984), I8-I9; T. A. Hickman, "Mania Americana”: narcotic addiction and modernity in the United States, I870-I920', Journal of American History, 29:4 (2004), I293; T. Seddon, 'The regulation of heroin: drug policy and social change in early twentieth century Britain', International Journal of the Sociology of Law, 35 (2007), I 49. 
social engineering by imperial progressives, whose regulatory dreams proved gestational in the emerging global order of nations. ${ }^{6}$

Yet opium provision was an anomalous development in these processes. It departed from a strong local trend in narcotics legal reform. From the I 890 , gold mine barons and their political allies advocated prohibitionist legislation - directed specifically against the sale and consumption of alcohol by African miners - as part of a quest to rationalize the labour process. For historians of South African state-formation who locate the origins of its coercive and segregationist modernity in the exigencies of mining capital, liquor controls represent a signal development. ${ }^{7}$ Charles van Onselen has chronicled how locally-produced alcohol for mine workers constituted the organic industrial base of Paul Kruger's Zuid Afrikaansche Republiek, with liquor manufacturing firms benefiting from state sponsorship and the president's personal advocacy. A means of generating capital surplus from an agricultural economy, alcohol was initially deployed in the recruitment and control of African migrant labour. Provision gave way to prohibition, however, as mine owners, American engineers, and other detractors of Kruger's state agitated around issues of worker discipline and productivity. ${ }^{8}$ As part of a broader progressivist agenda, they pressed for laws to close down drinking establishments and to curtail drunkenness and associated effects of absenteeism, crime, and workplace injury. Championed by Secretary of State J. C. Smuts, the Liquor Law (Act I7) of I 896 criminalized African consumption of alcohol and sales to African workers. ${ }^{9}$

Alcohol prohibition was among the first laws that Alfred Milner's cabinet reinstated after the South African war. It proved foundational for subsequent legal developments that Patrick Harries has described as an unfolding assault on the autonomy and bargaining power of African mine labour in this period. ${ }^{\text {IO }}$ From I903, concerns expressed by missionaries and others about disease and 'moral decay' arising in the 'drink-sodden' labour compounds of the Rand prompted a battery of reforms. ${ }^{\text {II }}$ Around alcohol, the issues of worker fitness and workplace surveillance coincided; medicine and law enforcement were drawn into a common regulatory frame.

On the medical front, Native Affairs Director Godfrey Langdon worked towards measures that could reduce mortality and morbidity on the mines. With backing from London, he succeeded in securing improvements in food and housing, medical care, and sanitation. Minimum standards for diet, hygiene, and hospital access were benchmarked

6 K. Breckenridge, The Biometric State: The Global Politics of Identification and Surveillance in South Africa, I 850 to the Present (Cambridge, 20I4), 20, 206-IO, and 2I3-I4; A. McKeown, Melancholy Order: Asian Migration and the Globalization of Borders (New York, 2008), I87-94 and 308-I7.

7 Marks and Trapido, 'Lord Milner', 52-4, 60-4, and 72-3; C. van Onselen, 'The modernization of the Zuid Afrikaanche Republiek: F. E. T. Krause, J. C. Smuts and the struggle for the Johannesburg Public Prosecutor's Office, I 898-1 899', Law and History Review, 21:3 (2003), 486-8.

8 C. van Onselen, New Babylon, New Nineveh: Everyday Life on the Witwatersrand, I886-I9I4 (Johannesburg, I982), 48, 64-5, 69-73, and I06; P. Harries, Work, Culture and Identity: Migrant Labourers in Mozambique and South Africa, c. I860-I910 (London, I994), I20-I.

9 Van Onselen, New Babylon, 73; K. Breckenridge, The Biometric State, 7I-2; Harries, Work, Culture and Identity, I3 $\mathrm{I}$.

Io Harries, Work, Culture, Identity, I32-7.

I I A. Jeeves, Migrant Labour in South Africa's Mining Economy: The Struggle for the Gold Mines' Labour Supply, I890-I920 (Montreal, I985), 50. 
through the Coloured Labour Health Ordinance of $1905 .{ }^{\mathrm{I} 2}$ Into the second decade of the century, and beyond, medical examination of labouring bodies became a standard means of monitoring disease. Inebriety was but one ailment within the catalogue of hazards screened by mine doctors. Compensation for silicosis and pulmonary tuberculosis began to be awarded from I9I2 and I9I6, respectively. ${ }^{13}$ Benefits of these progressive reforms to workers were contingent upon a regime of mine medicine that, as Jock McCulloch seeks to demonstrate, was systematically understaffed, prone to crude and racial diagnostics, and complicit in concealing from public scrutiny the nature and scale of occupational dangers and maladies, including the ruinous diseases originating in the work of blasting and drilling. ${ }^{\mathrm{I}}{ }^{\mathrm{N}}$

Alcohol prohibitions drove innovations in policing and in penal bureaucracy, as a robust illicit liquor trade emerged to fill the market gap. Harries shows that, despite consistent denials of efficacy by the Chamber of Mines and the persistence of a flourishing informal trade, liquor bans were in fact dramatically effective both in curbing alcohol supply and increasing labour discipline and measurable productivity. ${ }^{\mathrm{I}}$ Yet such effects were slow to emerge. The regulatory enthusiasm of progressives vied with a tradition of pragmatic tolerance for the anticipated 'vices' of an all-male labour force. ${ }^{\mathrm{I} 6}$ Van Onselen demonstrates how the I 897 liquor laws began to produce results only after proponents of divergent schools of thought joined forces. ${ }^{17}$ From I90I, Milner, eager to extend control over the mobility and behaviour of mine workers, as well as over immigrants whose entry was restricted or otherwise officially designated 'undesirable', invited Edward Henry to introduce fingerprinting as a scientific technique of identification. ${ }^{\mathrm{I} 8}$ This strategy of biometric registration met with intense resistance, notably by Indian residents who, under Gandhi's leadership, rejected its stigmatizing and discriminatory demarcation of uncivil status. $^{\text {I9 }}$

It is significant for the story of opium that the first comprehensive fingerprint register was crafted to identify, remunerate, and police indentured Chinese migrants. ${ }^{20}$ From 1906, this technology facilitated the experimental provision of an otherwise controlled 'poison' specifically for this labouring population. The inky presence of a thumb impression on a government-issue medical prescription for smoking opium acutely demonstrates the convergence of medical and penal machineries for managing chemical vitality on the Witwatersrand.

Legal provision did not function according to the intended designs of its promoters. Indentured Chinese migrants, certainly the primary targets and victims of shifting opium

\footnotetext{
I2 Jeeves, Migrant Labour, 50-5.

I3 J. McCulloch, 'Mine medicine: knowledge and power on South Africa's gold mines', Labour History, 54:4 (2013), 423 .

I 4 Ibid. 422 and $424-7$.

I 5 Harries, Work, Culture, Identity, I35-6 and I90.

I6 C. van Onselen, 'Who killed Meyer Hasenfus? Organized crime, policing and informing on the Witwatersrand, I902-8', History Workshop Journal, 67 (2009), 3.

I7 Van Onselen, 'Modernization', 503-4 and 506-I6.

I 8 Breckenridge, Biometric State, 63-89; C. van Onselen, 'Who killed Meyer Hasenfus?', 2.

I9 Breckenridge, Biometric State, 23-4 and 90-I I4.

20 Ibid. 24 and $79-82$.
} 
policy, demonstrated formidable agency as consumers and traders. Their resistance, first to prohibition and then to official drug maintenance, is evidenced by their ongoing preference for, or ties of obligation to, informal circuits of supply. This underscores both the importance of opium's local meanings and currency in the social relations of the compound as well as the limited reach of legislative authority. ${ }^{2 I}$

Yet, manifest failures of the official system did not weaken its efficacy in relation to other officially desired political and economic outcomes. The formal permit system, which essentially redefined smoking opium from intoxicant to medicine and awarded monopoly of legitimate opium sales and distribution to medical and pharmaceutical dispensers, cast drug provision as a scientific undertaking. Framed as an ethical medical measure, responsive to a culturally peculiar 'habit' of an imported population, the policy concealed the local and occupational aetiology of the addiction epidemic. Meanwhile, law enforcement and customs personnel directed their efforts not at opium consumption but rather at crossborder smuggling and illicit traffic, which tapped the revenue to be gained from authorized imports.

The shift from prohibition to provision was relatively short-lived. Regime changes in Britain and in the Transvaal saw the renewal of colonial political accountability to imperial public opinion and to the local white electorate. The drug provision policy was criticized on both fronts. It would be retained, under fire, for three years. In I909, with fewer than 2,000 Chinese workers still awaiting repatriation, Colonial Secretary J. C. Smuts presided over an amended law that administered the gradual suppression of opium in a show of conformity with emerging global consensus.

My argument here is that the state managed the politics of mass intoxication as an extraordinary problem of demography, achieved through the medical and penitentiary construction of a 'special biochemical zone'. Mine administrators and their law-making allies, along with organized medicine and pharmacy, acted upon the sound premise of the physical confinement, cultural ghettoization, and temporary status of the indentured Chinese labour force - a status contemporary critics identified as 'exceptional' and a contravention of 'the established principles of the liberty of the subject'. ${ }^{22}$

\section{ANTICIPATING OPIUM}

In the months leading up to the arrival of migrant Chinese labourers, the Transvaal government gave little thought to opium, virtually ignoring repeated queries from the Colonial

2 I Waetjen, 'Transvaal opium trade' (forthcoming).

22 Statement by Major Seely, 'Chinese labour in the Transvaal', African (South), 824:92 (I906), 279. Regarding the conditions of compound life of, and resistance by, Chinese mine workers, see G. Kynoch, 'Controlling the Coolies: Chinese mineworkers and the struggle for labor in South Africa, I904-I9I0', International Journal of African Historical Studies, 36:2 (2003), 309-29; G. Kynoch, "Your petitioners are in mortal terror": the violent world of Chinese mineworkers in South Africa, I904-I9 Io', Journal of Southern African Studies, 3 I:3 (2005), 53I-46; T. Huynh, "We are not a docile people": Chinese resistance and exclusion in the re-imagining of whiteness in South Africa, I903-1910', Journal of Chinese Overseas, 8 (2012), I40 and I37-68. 
Office that began arriving in March I904. ${ }^{23}$ To the extent that policy planning took place, opium was discussed in direct analogue to prohibitions of alcohol for African migrants. In early June, Foreign Labour Department (FLD) Superintendent Evans relayed his understanding that 'no intoxicants [were to] be given or sold to labourers in the compound except on occasion of Chinese holidays or high days and then only Chinese Samshu in quantities approved of by the Compound Manager'. ${ }^{24}$ Suggestion that a traditional drink be allowed for celebrations attracted the derision of Attorney General Sir Richard Solomon. Under the Liquor Act of I902, he explained, no intoxicating liquor could be given to 'coloured persons' and he was confident the courts would uphold 'that Chinese are coloured'. ${ }^{25}$

It was not until late June, with the transport of migrants underway that Milner sent hasty assurance of governmental intentions to regulate opium through two provisions under Section 29, subsection 7 of the Labour Importation Ordinance, worded as:

(I) No importer shall permit opium or any of the preparations thereof to be sold or kept for sale at any place on his premises, nor shall he permit the free issue of opium to any labourer in his employ; (2) No labourer shall introduce on the premises on which he is employed or at any time be in the possession of any opium or any preparation thereof. Any person contravening this regulation shall be liable on conviction to a fine not exceeding $£_{\mathrm{IO}}$ or in default of payment to imprisonment not exceeding one month. ${ }^{26}$

Such law was hardly practical, however, as it would criminalize all chemists and druggists, as well as all medical personnel who prescribed and dispensed opiated medications to their patients, including those attending ill and injured mine labourers. Lobbying by pharmacy and medical guilds, meanwhile, brought about a new Medical, Dental, and Pharmacy Ordinance (Act 29 of I904). ${ }^{27}$ It provided for the formation of a Medical Council and Pharmacy Board with advisory powers to the state. These bodies could now be drawn into law-making and attendant discussions around smoking opium policy.

Assurances that medical screening for chronic opium use took place at the sites of labour recruitment contributed to the initial regulatory lethargy around opium. According to Chamber of Mines Labour Importation Agency (CMLIA) advisor, G. Baldwin, the purpose of holding recruits at the labour camp in Tientsin was precisely to weed out chemically dependent candidates, a process he believed was mostly successful: '[I]t was sufficient for a medical officer examining recruits to even suspect that an applicant was an opium smoker to reject him. I have known twenty in a hundred rejected owing to this. ${ }^{28}$ From the very first voyages of transport, however, ship surgeons noted opium

23 Transvaal Archives Depot, Pretoria (TAB) FLD I/I47/2, Duplicate enclosure to Dispatch I65, 5 Mar. I904; Colonial Secretary of State to Transvaal Governor, I4 May I904; Governor's Office to Lieutenant Governor, 3 June I904; Attorney General's Office to Lieutenant Governor, 2I May I904; Governor's Office to Lieutenant Governor, 3 June 1904; Attorney General's Office to Lieutenant Governor, 2I May I904; Transvaal Governor to Secretary of State, I7 June 1904; Secretary of State to Transvaal Governor, I7 June I904; Attorney General to Lieutenant Governor, 24 June I904.

24 TAB FLD I/I 47/2, Governor's Office to Lieutenant Governor, 3 June I 904.

25 Ibid.

$26 \mathrm{TAB}$ FLD I/I 47/2, Governor to Secretary of State, 28 June I904.

27 M. Ryan, A History of Organised Pharmacy in South Africa, I885-I950 (Cape Town, I986), 57-8.

$28 \mathrm{KAB} \mathrm{MOH} \mathrm{322,} \mathrm{Copy} \mathrm{'Opium} \mathrm{on} \mathrm{the} \mathrm{mines} \mathrm{of} \mathrm{the} \mathrm{Witwatersrand';} \mathrm{Assurances} \mathrm{of} \mathrm{the} \mathrm{efficacy} \mathrm{of} \mathrm{medical}$ screening for opium use was forthcoming from many sources: see Richardson, Chinese Mine Labour, 85. 
use on board and its apparent detriments to wellbeing. ${ }^{29}$ The trade that developed on the rand, however, was the work of formal and illicit import operations.

Early efforts of mine magnates to downplay the presence of opium on the mines can be seen in the assurances of Lionel Phillips, director of Wernher-Beit and Eckstein, who

made enquiries in regard to the question of opium smoking, and $\mathrm{Mr} \mathrm{W}$. T. Anderson of the Glen Deep, who has in his charge over 2,000 Chinamen, and who is one of the most intelligent and respected of mine managers, tells me that, while a great many Chinamen occasionally indulge in a few whiffs of opium, the vast majority of them show not the least disposition to excessive indulgence in that pernicious habit. He has discovered and dealt with one or two bad cases, but he states that excessive opium-smoking among the Chinese is a very rare occurrence. Chinamen usually smoke a little opium as we should drink a glass of beer, and it is only in the most exceptional cases that they have evinced any sign of losing their self-control. ${ }^{30}$

Fred W. Godsil, a Controller of Chinese on the Princess and Tudor Mining estates, however, recounted a very different experience of the drug's effect in the workplace:

Of late, it has been affecting my men to such an extent that it was a difficult matter to turn out my full percentage of men to work daily. Apart from this, my percentage of sick and in hospital were increasing daily, which is a very serious matter where Chinese labour is being so extensively employed on the Rand.... It is a very hard matter for me to catch my men smoking opium in their quarters, as when they see me approaching, they give the password, there being sufficient time for those smoking to conceal their pipes etc., taking the precaution beforehand to fumigate the room with burnt brown paper or candle grease. Of late they have taken their pipes and opium to smoke underground; this I have detected strongly while visiting the stopes underground. Those addicted to opium are easily marked by their lazy and careless habits and the only efficient way to get satisfactory work from my men is to keep a strict watch and suppress all opium smoking. ${ }^{3 \mathrm{I}}$

As widespread use became irrefutable, with a range of 'evils' increasingly attributed to it, the origins of the drug became a point of political dispute. In Baldwin's assessment, 'ninety-eight per cent [of opium smokers on the mines] ha[d] either taken their first pipe of opium coming over in the steamer or since they ha[d] arrived in the Transvaal'. ${ }^{2}$ General Manager of CMLIA Walter Bagot, also insisted that the problem was locally made. '[T]he Coolies from Northern China as a class are in very poor circumstances and opium in Northern China is an expensive luxury and practically out of their reach, here on the Mines the Coolies have plenty of money and can afford it.'33 Johannesburg Commissioner of Police E. M. Showers also believed that most initial encounters with the drug had occurred 'after leaving China', the 'peasant' origins of migrants contributing to local 'indulg[ence] in what they consider a luxury which they cannot afford in their own

29 A. MacDonald, 'Durban-bound: Chinese miners, colonial medicine and the floating compounds of the Indian Ocean, I904-I907', Journal of Natal and Zulu History, 23 (2005-6), I40.

30 L. Phillips, Transvaal Problems: Some Notes on Current Politics (London, 20I3 [orig. pub. I905]), I IO-I I and 123 .

3 I TAB FLD 230 68/52, Statement by Labour Controller Fred W. Godsil, I 5 Jan. I 905 submitted to FLD by General Manager, Princess Mines, 28 Jan. I905.

$32 \mathrm{KAB} \mathrm{MOH} \mathrm{322,} \mathrm{Copy} \mathrm{'Opium} \mathrm{on} \mathrm{the} \mathrm{mines} \mathrm{of} \mathrm{the} \mathrm{Witwatersrand'.}$

33 TAB FLD I/I47/2, CMLIA Manager to Lieutenant Governor, I Aug. I905. 
398 VOL. 57, NO. 3 POPPIES AND GOLD: OPIUM AND LAW-MAKING ON THE WITWATERSRAND, I904-Io

country'. ${ }^{34}$ Other government administrators, however, pronounced the presence of opium addiction on the mines an entirely alien import, the failure not of local controls but of labour recruiters. Colonial Secretary Patrick Duncan, for example, expressed it as 'unfortunate' that, when government had arranged to import 'a large number of Chinamen as labourers', the migrants had 'brought their habits with them'.35

In this early period of uncertainty, at least two enterprising civilians proposed local poppy cultivation and a formal system of drug provision modelled after the opium farms of the Straits Settlements. ${ }^{36}$ Beyond suppression, however, no policy solution had yet been officially imagined. Few parties believed that complete prohibition was possible but, in I905, two laws and a number of proclamations attempted to 'make it very much more difficult than it is now for persons to obtain opium in this country for illicit purposes' 37

\section{LEGISLATING OPIUM 1905: PROHIBITION AND ITS DISCONTENTS}

Under the 1904 Pharmacy Act, the Medical Council and Pharmacy Board were granted authority to classify therapeutic substances and 'poisons', and to oversee regulatory policy. The attorney general soon solicited that authority, requesting that 'opium' be reclassified in the poison schedule and upgraded to facilitate greater controls 'in view of serious consequences which would arise from the unlimited sale and use of opium'. ${ }^{38}$

Responses from both professional bodies indicated they well understood that the state's aim was specifically 'prohibition of the sale of [smoking] opium to Chinese'. ${ }^{39}$ The Medical Council proposed that opium 'in its raw state' should be upgraded as a poison. ${ }^{\circ}$ The Pharmacy Board recommended further specifications: 'gum opium' and 'extract of opium' should be designated in Part I of Schedule Three, placing it among the most rigorously controlled substances. 'Preparations of opium' and 'preparations of poppies' - used by pharmacists in 'patent', ' proprietary', and 'Dutch' medicines - should be retained within the less stringent Part II class. ${ }^{4 \mathrm{I}}$ With regard to these various forms and subcategories, the Under Secretary admitted he was out of his depth: 'The Medical Council talks about opium in its raw state. Does that expression include gum opium and extract of opium?' 'Yes', returned the assistant colonial secretary, 'but the pharmacy board

34 TAB CS 883, Police Commissioner to Secretary of the Law Department, 9 May I907.

35 Debates of the Transvaal Legislative Council (hereafter Legislative Debates), 30 July I906, 895.

36 TAB FLD 230 68/52, Lee Choo Kong to E. Evans, 2I Jan. I905; TAB GOV 806 PS 9/24/o5, Correspondence between Lyle Heath LRCSI of Johannesburg and Assistant Private Secretary Howick for Governor's Office, Sept. I905.

37 Legislative Debates, 26 Sept. I905, 2 I 58.

38 TAB CS 554 I497, Acting Secretary of the Law Department to Acting Assistant Colonial Secretary, 20 Dec. I904.

39 TAB CS 554 I497, Lieutenant-Governor to Assistant Colonial Secretary, I I Mar. I905.

40 TAB CS 554 I 497, Acting Secretary of the Transvaal Medical Council to the Assistant Colonial Secretary, Io Feb. I905.

4 I TAB CS 554 I497, Acting Secretary to the Pharmacy Board to Assistant Colonial Secretary, 7 Mar. I 905 with attached copy of Resolution. For an overview of various medicines in this context, see A. Digby, 'Self-medication and the trade in medicine within a multi-ethnic context: a case study of South Africa from mid-nineteenth to mid-twentieth centuries', Social History of Medicine, I8:3 (2005), 439-57. 
definitions are better and indicate the two forms of opium found in the [smoking opium] trade.' When Resolution No. 420 was gazetted in March I905, it carried the wording and definitions of the Pharmacy Board. ${ }^{42}$

That same month, in a confidential communication to the lieutenant governor, CMLIA Manager Walter Bagot warned that reports from various mine sites confirmed that 'the illicit sale of opium for Chinese Coolies [was] increasing rapidly'. He had learned that 'some few weeks back, several chemists in this Town were detected selling opium in considerable quantities'. Police Commissioner Showers had submitted a report to the law department requesting advice on whether to institute proceedings against the chemists but there had been no reply. ${ }^{43}$

In his quest to tighten drug control, Bagot elicited the Pharmacy Board's cooperation. In mid-April he requested input from its president, James H. Dinwoodie, a manufacturer and importation chemist from England who owned two Johannesburg pharmacies and advertised his establishment as 'Contractors to the Transvaal Government'. Bagot had four measures to propose: increase in the severity of punishments for violators of the Medical, Dental and Pharmacy Act; an amendment to that Ordinance criminalizing possession of any Part I poison; establishment of a maximum amount of opium that a given chemist and druggist could keep on his premises; and amendment to the 1903 Customs Convention that would place a 'very heavy duty on preparations of opium' ${ }^{44}$

Dinwoodie and his board declared themselves unable to recommend the second and third proposals. The first and last measures would be acceptable if reworded to reflect that only gum opium and extract of opium were being targeted. They would oversee inspections of chemists' poison books, their prerogative under Section 57 of the Pharmacy Act. ${ }^{45}$ The CMLIA board meanwhile suggested that opium possession by and sales to 'labourers' as defined in the Labour Importation Ordinance should be 'absolutely and specifically' prohibited 'on the same lines of Sections 46 and 48 of the Liquor Licensing Ordinance of I902'.46 Superintendent J. W. Jamieson, Evans' replacement in the FLD, urged that all proposed measures should be put into effect as soon as possible. ${ }^{47}$

Jamieson raised the issue of opium use in his FLD Annual Report of June I905. 'Effects of opium' could be considered the cause of 'a certain proportion' of reported cases of illness and of 22 deaths by overdose. ${ }^{48}$ Representing 5 per cent of a total of 469 recorded fatalities, this was a relatively minor hazard when weighed against accidents $(25$ per cent), beriberi ( 8 per cent) and dysentery ( 13 per cent). Yet broken down by month, death from opium poisoning - unlike all other listed pathologies - showed a dramatic

42 TAB CS 554 I 497, Under Secretary to Lieutenant-Governor, 22 Mar. I905.

43 TAB FLD I/I 47/2, General Manager of the Chamber of Mines Labour Importation Agency Walter Bagot to Lieutenant-Governor, 3 Mar. 1905.

44 TAB FLD ז/147/2, Walter Bagot to J.H. Dinwoodie, President of the Transvaal Pharmacy Board, I3 Apr. 1905.

45 TAB CS 554 I497, Acting Secretary of Transvaal Pharmacy Board to Walter Bagot, I9 May 1905.

46 TAB CS 554 I 497, Bagot to Colonial Secretary, 29 June 1905.

47 TAB CS 554 I497, Jamieson, FLD Superintendent to Under Secretary, Colonial Secretary's Office, I3 July 1905 .

48 'Opium habit' was not itemized among illnesses for this year. 
increase not explained by the growth in numbers of arriving migrants. ${ }^{49}$ 'Excessive' opium smoking had resulted in I 5 cases of repatriation. The report conveyed assurance that imminent legislation would regulate opium in the compounds 'along the same lines as Sections 46 and 48 of the Liquor Licensing Ordinance of I902'. ${ }^{\circ}$

These reforms appeared in the Labour Importation Amendment Ordinance, Act 27 of I905, and came into effect in September. Added to Section $3 \mathrm{I}$ of the original Act were two clauses. The first prohibited acquisition and possession of 'gum opium, extract of opium and preparation of poppies' by all persons defined as 'labourers' under the Ordinance. Offenses were punishable by fines of up to $£ 20$ or a maximum of 3 months in prison with the possibility of hard labour. The second clause indicated that 'any person' supplying a labourer with these substances 'except for medicinal purposes' would be liable to a similar prison term and a fine up to $£_{\mathrm{I}} \mathrm{OO}$.

These new measures, however, did not address the growing quantities of opium flowing into the Transvaal from outside its borders. In August, Walter Bagot once again confidentially informed the lieutenant governor that rates of addiction were increasing: ' $[\mathrm{M}]$ any coolies who had not the opium habit on arrival in this country are contracting it here.' Increases in supply indicated a rise in quantities imported: 'We are totally certain that large quantities of opium have lately been, and are still being imported, into the Transvaal, chiefly to the Rand. ${ }^{51}$

Prior to I904, chemists imported opium in small amounts, ranging from a single ounce to 2 lbs quarterly, for small-scale dispensing or general manufacture. ${ }^{52}$ Against this baseline, increases in quantities of opium were exponential. ${ }^{53}$ In letters to the law department, the Johannesburg police commissioner confirmed that a Braamfontein chemist, $\mathrm{Mr} \mathrm{A}$. $\mathrm{H}$. Jones had imported one and a half tons of opium, immediately disposing 15 cwts 'principally to Chinese'. Further, 'opium of about four tons is imported monthly by six importers'. Scrutiny of chemists' and retailers' records offered no information but 'there is little doubt that the bulk ... finds its way to the Chinese quarters in Johannesburg and from thence to the Chinese labourers.' ${ }^{54}$ Reports also indicated that a large of amount

49 FLD, Annual Report of Foreign Labour Department (hereafter FLD Annual Report), I904-I905 (Pretoria, I906), I9. Only two recognized overdose deaths occurring before March I905 but then II in June alone. At the end of March of 1905 this population stood at 34,20I6; at the beginning of June it was 4I,305 (FLD Annual Report, appendices). Discrepancy in reporting (table calculates deaths at 22, narrative 2I). Causes of two hundred additional deaths en route to and from the Rand are not identified.

50 FLD Annual Report, I905, I9-2I.

5 I TAB FLD I/I47/2, Bagot to Elgin, I Aug. I905.

52 Chemists and general retailers sold opiated medicines and preparations over the counter and by prescription. See Ryan, A History of Organized Pharmacy, 25; V. Berridge and S. Mars, 'Glossary history of addictions', Journal of Epidemiology and Community Health, 58:9 (2004), 747-50; Digby, 'Self-medication', 45 5-6.

53 Calculating, and determining the significance of, various quantities and forms of opium was a chronic difficulty for law-makers and one of several ambiguities allowing manipulation by interested parties. At least four systems of measurement and quantification are evidenced to be in use for opium in this context: Avoirdupois, Apothecaries, Tola (Vedic), and 'chests'. See Courtright, Dark Paradise, I96n54, for analogous problems of quantification in the US; also I94n46, regarding variations in the active alkaloid content in poppies. For an example of how morphine content can complicate opium quantifications and politics, see A. Farooqui, 'Colonialism and competing addictions: morphine content as historical factor', Social Scientist, 32:5/6 (2004), 2 I-3 I.

54 TAB LD II33 AG/44II/05, Police Commissioner to Secretary of the Law Department, 2i Sept.I905. 
of gum opium had been cleared at Port Elizabeth as 'gum meconium [sic]' and consigned en route to Bloemfontain and from there to Johannesburg. ${ }^{55}$

Police intelligence proved crucial in early September when Sir George Farrar, mine magnate and stalwart progressive in the legislative council, raised the issue of opium law reform, requesting import figures from July I904. ${ }^{56}$ The colonial secretary could only report opium as an itemized import for the first half of 1905, an amount he cited as 3,50olbs. However, since July, 'large consignments' had been arriving. ${ }^{57}$ Opium, explained Farrar, was being imported 'not only by chemists but by ordinary merchants' and sales of opium in the colony were 'more or less unrestricted'.

[I]n August [1905] one firm alone imported a ton and a half. I am informed and I can give the names that $336 \mathrm{lbs}$ of opium were sold in one day to one customer. There is another firm that imports many hundredweights per month. There is one firm that consigned four cases of opium to a certain railway station, which are now, I believe, in the possession of the station master. Another firm imports 5 oolbs of opium per month [.] ${ }^{58}$

This, Farrar suggested, constituted an 'illicit trade'. ${ }^{59}$ Provisions made through the Medical and Pharmacy Act of 1904 had proved unenforceable and a new ordinance was required to halt imports and give teeth to police investigations.

Discussions by government produced the Opium Importation Ordinance (Act 36 of I905) promulgated on 2 October. It declared the unlawfulness of 'any person except a registered medical practitioner, dentist or chemist and druggist' to import into the Transvaal any of the three forms of opium specified in the Labour Importation Amendment Ordinance. It introduced new application procedures for obtaining opium import permits by authorized parties, which would be processed by the colonial secretary's office. The director of customs could detain opium imported unless or until a valid permit was produced. Police had powers - with or without a warrant - to search 'any premises, wagon, cart or other vehicle' suspected of holding contraband opium, which could then be seized and removed. Persons found in possession of opium who were not registered professionals with a valid permit - except where opium was designated 'for medicinal purposes' - faced fines of up to $£_{5} 00$ and prison terms of six months. The Ordinance was applied by Proclamation also to Swaziland (No. I I of I905). ${ }^{60}$

The 'medicinal purposes' clause would prove a significant loophole. Following promulgation of the Ordinance, the state again drew upon the chemical and professional knowledge of the Medical Council and Pharmacy Board. The assistant colonial secretary wrote to each organization requesting advice on two issues crucial for assessing the forthcoming opium import applications. The first issue pertained to quantities: what was a 'reasonable

55 TAB LD II33 AG/44II/05, Assistant Colonial Secretary to the Law Department, 7 Sept. 1905.

56 Legislative Debates, 5 Sept. 1905, I 598. Within Farrar's Anglo-French Company, Chinese recruits made up 49 per cent of unskilled mine labour, the highest percentage of any mining group. P. Richardson, 'The recruiting of Chinese indentured labour for the South African gold-mines: 1903-1908', The Journal of African History, I8:I (I977), Iог.

57 Legislative Debates, 5 Sept. 1905, I 598-9.

58 Ibid. 6 Sept. 1905, 1675.

$59 \mathrm{Ibid}$. $1675^{-6}$.

60 TAB CS 625 4566, Secretary for Swaziland Affairs to Assistant Colonial Secretary, 24 Oct. 1905. 
amount' of opium that an authorized chemist or druggist could import? The second issue was how to determine whether a given applicant could be considered professionally qualified (or otherwise authorized) to import opium under the Act. ${ }^{6 \text { I }}$

W. A. J. Cameron, secretary of both professional bodies, reported that the Pharmacy Board was willing to assist. Every application could be submitted to the board members for inspection, to 'make certain that such quantities as are applied for are reasonable' and to assess the professional standing of the applicant.

The Pharmacy Board had a query of its own: did the new import law prohibit possession of opium for smoking purposes by Indian and Chinese merchants 'for whom the drug has long been a necessity'? More specifically, would it be lawful for a medical practitioner to grant a prescription or permit to 'such persons' on the grounds that it was for medical purposes? '[T]he board is desirous to know how far Medical Men and Chemists may go in supplying opium in such bona fide cases. ${ }^{62}$ The reply from the assistant colonial secretary must have been as welcome as it was vague:

$[R]$ egarding the possession of opium the law clearly permits the possession of a reasonable quantity of opium for medicinal purposes, and if a Medical Practitioner should prescribe that it is essential to the health of the patient that he should smoke opium I do not think that any court would convict of illegal possession. ${ }^{63}$

In effect, the Pharmacy Board now possessed authority to determine 'reasonable quantities' and also what quantities were reasonable for which provider - leverage, certainly, to shape the fortunes of many. Most crucially, druggists and chemists now had licence to dispense smoking opium when medically prescribed.

Clearly privy to this exchange, in early December the executive committee of the Medical Council requested clarity about the 'supplying of opium for smoking purposes on the prescription of a Medical Practitioner'. ${ }^{64}$ The importation law evidently allowed prescription of smoking opium for 'medicinal purposes'-but how was this to be defined? Was provision of opium to addicted individuals a legally acceptable medicinal use?

It is well known to the medical profession that confirmed opium smokers when deprived of the drug may get ill and die, and it has been held by yourself, and also by the Council that a Medical Practitioner may supply the drug for smoking purposes if he considers it essential to the health of the patient, and that the law permits the possession of a reasonable quantity for medicinal purposes. ${ }^{65}$

6I TAB CS 625 4566, Assistant Colonial Secretary to W. A. J. Cameron, Secretary of the Transvaal Pharmacy Board and Medical Council (undated copy).

62 TAB CS 625 4566, Cameron to Assistant Colonial Secretary, 23 Oct. 1905.

63 TAB CS 625 4566, Assistant Colonial Secretary to W. A. J. Cameron (undated).

64 TAB CS 625 4566, Cameron to Assistant Colonial Secretary, 2 Dec. 1905.

65 Ibid. The medical officer of health of the Cape Colony summarily dismissed the idea of deprivation as lethal, as did others. See T. Waetjen, 'Drug dealing doctors and unstable subjects: opium, medicine and authority in the Cape Colony, I907-1910', South African Historical Journal, 68:3 (2016), available online: http://dx.doi. org/IO.IO80/02582473.20I6.I230644. For a summary of medical debates about deprivation and treatment in Britain during this period, see I. Walmsley 'Opiate substitution treatment: poisoned bodies and the history of substitution', Contemporary Drug Problems, 40 (2013), 400-4, esp. 402. 
Against the prospect of widespread calamity, the Medical Council requested to learn the perimeters for prescribing the drug for patients suffering the effects of abstinence. Under the law, what could be considered a reasonable quantity of opium to prescribe? And, what form should the prescription take?

In fact the Council was prepared with answers to both these questions. They had 'been informed that confirmed smokers may use any quantity between I and 4 lbs per month'. If this was indeed the case, '[o]rdinary prescriptions' would be open to 'grave abuse' since they allowed more than one chemist to dispense a listed item to a single patient. A special prescription format could help avert this danger, one that would state the total quantity of opium allowed within a single month and require individual suppliers to verify amounts and dates of incrementally dispensed quantities. ${ }^{66}$ The assistant colonial secretary rejected the latter suggestion, explaining: 'It is not possible with the law as it stands to adopt the remedy suggested ... [because] the law does not allow the government to restrict prescriptions for opium by medical practitioners'. ${ }^{67}$

The 'medicinal' loophole in the 1905 legislation, identified and exploited by the Medical Council and Pharmacy Board, would prove a key mechanism for the growth of opium trade and consumption on the Rand. In addition to, and articulating with, other forms of traffic, the broad licence for provisioning opium on medical prescription would render prohibition - the stated aim driving 1905 legislation - an impossibility. Meanwhile, explosive developments in the relations of production on the mines would draw the issue of opium into a new frame of relevance for mine managers, first in defensive explanations of labour unrest and violence and, later, under new political pressures, within a project of labour control.

\section{LEGISLATING OPIUM 1906: MEDICINE AND MAINTENANCE}

A year later, the 1905 legislation was pronounced 'almost a dead letter' in a report by mine administrators and by the Chamber of Mines. ${ }^{68}$ Not only had it failed to impede the growth of illicit trade in opium, it had stimulated a vast increase of supply from legitimated sources through the medicinal use clause. As the attorney general explained to the Transvaal Legislative Council, doctors could prescribe (and dispense) smoking opium and chemists and druggists were not only hard pressed to ensure their stocks kept up with demand, but faced increased competition from peers and illegal dealers. As the Medical Council had indeed predicted, 'the same prescription might be used over and over again to an extent never contemplated'. ${ }^{69}$ In 1906, both opium laws of the previous year were repealed and replaced with a new one, an Opium Trade Regulation Ordinance (Act no. 25).

66 TAB CS 625 4566, Cameron to Assistant Colonial Secretary, 2 Dec. I905.

67 TAB CS 6254566 , ACS to SMC, 7 Dec. I905.

68 Extract from report of the Committee of Mine Managers to the Chamber of Mines. Quoted in a letter to Sir Richard Solomon, Attorney General, from the Chamber of Mines, Pharmacy Board and Medical Council. Published Chamber of Mines, Annual Report i906, I I I.

69 Legislative Debates, 25 July I906, 882. 
Conditions of instability and extreme violence on the mines, as well as in surrounding civilian areas, renewed local and British debates about the Chinese labour 'experiment'. Flogging and other punitive measures employed to quell waves of labour protest prompted formal investigation into worker control. ${ }^{70}$ The Special Committee on the Control of Chinese Indentured Labourers reported in May 1906 that the 'opium habit' was 'rife' and increasing:

Excessive indulgence in the habit lessens the earning capacity of the coolie ... The traffic in opium is a most difficult one to stop. Instances have been given in which doctors have furnished medical certificates enabling individuals to obtain a certain amount of opium. These individuals are then in a position to go around and buy the quantity prescribed by the doctor in a considerable number of chemists' shops along the reef ... By this method, then, individuals are enabled to acquire a sufficient quantity of the drug to do a big trade in opium amongst the labourers. ${ }^{7 \mathrm{I}}$

With accusations of Chinese slavery on the Rand strengthening the electoral platform of British liberals, questions about opium once again arose in the House of Commons. ${ }^{72}$

The FLD's second annual report reflected increases in rates of smoking opium consumption. Between the amendment to the Labour Importation Ordinance in October I 905 and June I906, 462 Chinese workers had been convicted and sentenced for possession of opium in terms of Section 8, Sub-section 15 of that Act. ${ }^{73}$ Opium overdose was held responsible for II 7 fatalities for that year, I 3 per cent of all deaths, second only to accidents at 32 per cent. ${ }^{74}$ 'Opium habit' was responsible for 693 reported instances of illness. ${ }^{75}$ Contemporary critics, including doctors and civil servants, suggested that opium use was rampantly underreported (whether intentionally or not) and that symptoms of addiction and withdrawal were subsumed within diagnoses of debility, rheumatism, dysentery, 'other digestive troubles', fever and influenza, and muscle aches. ${ }^{76}$ Discrepancies in the reporting of medical repatriation cases corroborate such suspicions. A significant number of individuals identified by mine administrators as sufferers of beriberi, debility, rheumatism, and dysentery were, by the examining

70 Kynoch, 'Controlling the Coolies', 3 I4 and 3 I 8; Huynh, “Not a docile people”, I 53.

7I Report of the Special Committee on the control of Chinese indentured labourers. In Chamber of Mines, Annual Report, I907.

72 L. van der Walt, 'Anarchism and syndicalism in South Africa, I904-I92 I: rethinking the history of labour and the left' (unpublished PhD thesis, University of the Witwatersrand, 2007), I 58, cited in Huynh, " Not a docile people”', I6Ini6; TAB FLD I/I47/2, Elgin to Selborne, 30 Mar. I906, with Enclosure, query I2 Mar. I906.

73 FLD Annual Report, I905-I906, Appendix 2.

74 FLD Annual Report 1905-I906. Percentages sensitive, of course, to other factors, such as the declining beriberi epidemic: see Appendix 6. Jamieson hoped that, with legislation being introduced 'for the prevention of excessive use of opium' that there would be fewer deaths related to opium poisoning in the year to follow, 27.

75 FLD Annual Report I905-I906, Appendix 5.

76 For example, TAB LD I4I3 AG8I3/07, E. Mundy to Secretary of Law Department, I 5 Mar. I907: 'In the schedule of sickness prepared by the Medical Officer of Health for the Witwatersrand there will be found two columns set apart for such of the coolies who are suffering from diarrhea and debility respectively .... . That both of these diseases would follow the sudden withdrawal of opium from victims of that habit is not only possible but probable'. 
physician, rediagnosed and re-classified as 'opium habit'. ${ }^{77}$ These recalibrations were not represented in official reports.

Regardless of the actual extent of opium use, mine management cited opium 'vice' and trafficking as a cause of labour unrest. Opium smokers and gamblers were accused, for example, of frightening boss boys into go-slow worker actions to discourage drilling productivity and undermine a system of financial incentives. Debilitated by their habit, chronic opium users ostensibly stood to lose economic ground against their more able-bodied peers when management introduced bonuses for those workers who exceeded per diem drill minimums. ${ }^{78}$

In his June 1906 Annual Report, FLD Superintendent Jamieson unleashed a disparaging barrage against Chinese 'character' and culture to defend brutal labour controls on mines. While denying involvement of mine personnel in opium traffic, he blamed the acute problem of desertion on 'gambling ... supplemented by an illicit trade in opium':

The opium habit is fostered and kept alive by certain unprincipled 'whites', who contrive to do almost as great an illicit trade in this commodity as is done in liquor, sold to the Kaffirs by the same class. The price of opium sold illicitly, which is largely adulterated prior to sale, being so much above the coolie's means, he borrows heavily to obtain it, and finding no means of paying such or other debts, he is compelled to desert, and after days of wandering becomes desperate through starvation and robs in order to live. ${ }^{79}$

Pointing to price, adulteration, and difficulties of access as reasons for high desertion rates, the FLD report hinted at the rationale underpinning new official thinking about opium supply. Prohibition was, in fact, no longer on the agenda. Indeed, the committee investigating control of Chinese Labourers had reported that: 'It has been suggested to us by some compound managers that the drug should be dispensed under government or mine control. ${ }^{80}$ The Chamber of Mines, Pharmacy Board, and Medical Council jointly petitioned for new measures to be introduced. These bodies were adamant that opium required further controls but were 'not prepared to recommend that the dispensing of opium to Chinese should be absolutely prohibited', warning that abstinence held potentially lethal consequences for those 'already contracted to the opium habit'. ${ }^{8 \mathrm{I}}$

On 25 July, the acting attorney general introduced a new draft ordinance, created in consultation with the Chamber of Mines, Medical Council, and Pharmacy Board, to the

77 Adler Museum archive, University of the Witwatersrand, Johannesburg. Medical repatriation lists for the Katherine Park, Aug. I905, and Indravelli, Oct. I905. Diagnosis, and whether an ailment was contracted 'before' or 'since' arrival on the Rand, determined responsibility for costs of repatriation, another possible reason for discrepancies. In the medical repatriation lists I was able to access, cases re-diagnosed to 'opium habit' were re-designated by the medical examiner to 'since', an indication that addiction was viewed a locally acquired condition.

78 P. Richardson, 'Coolies and Randlords: the north Randfontein Chinese miners' “strike” of I905', Journal of Southern African Studies, 2:2 (I976), I67. Also in Kynoch, 'Controling the Coolies', 320.

79 FLD Annual Report, I905-I906, II.

80 Report of the Special Committee on the control of Chinese indentured labourers, May I906. In Chamber of Mines, Annual Report, I907.

8I Chamber of Mines, Annual Report, I906, Letter to Sir Richard Solomon, Attorney General, from J. N. de Jonah for the Chamber of Mines, R. Butters (acting president) for the Pharmacy Board and W. T. F. Davies for the Medical Council, 28 June I906, I I I. 
Transvaal Legislature. Previous law, he declared, had 'provided no safeguard against an excessive quantity being obtained'. ${ }^{82} \mathrm{New}$ legislation was proposed, as followed: '[O]rdinary members of the public' seeking a permit to possess 'gum opium' or 'extract of opium' through medical prescription would be required to obtain the endorsement from a resident magistrate, assistant resident magistrate, or resident justice of the peace. In the case of bonded miners, mine doctors were placed in charge of receiving applications and writing prescriptions; FLD inspectors would award official permits. In all cases, finger impressions would be furnished for the permit, and a counterfoil kept for purposes of identification. A single permit would be good for six months, dispensed in instalments to be recorded by the authorized supplier, their record books open to inspection by police and FLD officials. A maximum monthly amount of opium was set at $2 \mathrm{lbs}^{8}{ }^{3}$ George Taylor, the medical officer of health for the Transvaal, explained to his Cape Colony counterpart, how he settled upon this maximum amount:

In a letter dated 20 December 1905 , the Chinese Consul-General 'Lew Yuk Sin' recommended that an average of 2 ozs per diem should be considered a maximum quantity for a confirmed smoker. This would mean $5 \mathrm{lbs}$ Apothecaries or $33 / 4 \mathrm{lbs}$ Avoirdupois. So $2 \mathrm{lbs}$ was fixed as the maximum for one person per month. ${ }^{84}$

The draft ordinance invoked a range of objections. A. S. Raitt, an engineer, trade union leader, and avid defender of white unskilled labour, proclaimed himself 'astonished' by the prospect that 'ordinary white patients' and their physicians were to be monitored by government. If the aim was to check abuse, was a magistrate qualified to check the prescription of a doctor? If not then 'what check was there in it at all? [A magistrate] had merely to endorse it; he could not say that the doctor had given too much or too little. ${ }^{85}$ Raitt had

no objection to stringent regulations being made in regard to Chinese, but he had the strongest objections to the rest of the community being degraded to the same level, and especially he had the strongest objection to any interference between a medical practitioner and his patients. The wording used - 'Opium or extract of opium' might be made to cover any sort of preparation or tincture in which an extract of opium could be found. ${ }^{86}$

Raitt motioned that, where the law referred universally to 'person' in Clause 8, this word be deleted and replaced with the words 'labourer introduced into this Colony under the Labour Importation Ordinance, 1904 ${ }^{87}$ Against these and similar objections, the attorney general explained how clever wording and key aspects in the draft made this an ordinance exclusively directed to 'Chinese labourers and other Asiatics'. The Medical and Pharmacy Board had, for this reason, assured government that 'the law would not interfere with the ordinary prescriptions given to white people by doctors' ${ }^{88}$ Appraised, through the

82 Legislative Debates, 25 July I906, 882.

83 Ibid. $882-3$.

$84 \mathrm{KAB}$ MOH Gi 7 b, George Taylor, Medical Officer of Health of the Transvaal Colony to A. John Gregory, Medical Officer of Health of the Cape Colony, 4 Sept. 1907. Inverted commas in original.

85 Legislative Debates, 25 July I906, 883-4.

86 Ibid. 884 .

87 Ibid. 30 July I906, 892.

88 Ibid. $893-4$. 
protracted discussion that followed, of the law's racial coding of opium and the fixing of normative medicinal uses to white, civic bodies, Raitt withdrew his motion. ${ }^{89}$

The key controversy in this debate, however, resided in the shift from prohibition to provision. E. F. Bourke, representing South Central Pretoria and an Independent, demanded to be told whether the drug was, in essence, to be deployed as a formal mechanism of labour control. He wished it to be stated explicitly

whether it was the intention of the government to allow the sale of opium to Chinese labourers on the mines. If so, [the draft ordinance] appeared to be an entire innovation. It appeared ... that there was such an intention. If it were represented to the [mine] Inspector that the coolies could be better managed if they had a fair supply of the drug given to them, the supply would naturally be forthcoming. ${ }^{90}$

An amount of 2 lbs per month, he observed, suggested this was precisely the rationale. Indeed, it seemed the law would have an 'exactly contrary' effect to the stated intentions of control in that it

would not only make it permissible but would involve the practically universal use of the drug. 2lbs was an extraordinary amount to allow. There was nothing to prevent a labourer obtaining that quantity at any one time for his personal use, and he must use it within a month. ${ }^{\text {I }}$

Bourke contended that the 'the whole tenor of the [draft ordinance] was in the direction of increasing the supply to the labourers'..$^{22}$ Its title was a misnomer; it should have been named the 'Opium Licensing Draft Ordinance' and it 'appeared clear that the Government looked forward to a large sale of the drug to coloured labourers'. ${ }^{93}$ Moreover,

[w] ho were the gentlemen who had advised the Government with regard to that? The men who were going to sell it, and the men responsible for giving prescriptions were the men who had advised the Government as to the amount to be supplied. It was the duty of the Government to further inquire into the matter before bringing forward such a Draft Ordinance. Whereas, in prior times it was necessary that an independent man, a man not concerned with the mines, and a man who would be responsible for any ill effects that might take place, should give the prescription, now it was [to be] the mine doctor who gave the prescription. ${ }^{94}$

With evident sarcasm, Bourke reminded the assembly that opium was an addictive and dangerous substance: he had not himself used the drug but had it on 'the best authority that once the habit was commenced one was compelled to use increasing quantities'. ${ }^{95}$ It appeared that provision for opium use would now be available 'to any coolie in the compound'. ${ }^{96}$

The acting attorney general admitted that government did intend, through the Ordinance, to authorize the sale of opium to Chinese labourers. He explained, however,

\footnotetext{
89 Ibid. 903 .

90 Ibid. $89 \mathrm{I}$.

9I Ibid. 896.

92 Ibid. 897.

93 Ibid. 895 .

94 Ibid.

95 Ibid. 903 .

$96 \mathrm{Ibid}$.
} 
that the 2 lbs maximum in effect constituted a reduction in the quantities currently being endorsed through loopholes in earlier laws.

As debate continued, defenders of the ordinance simultaneously presented two somewhat contradictory arguments in favour of provision - one therapeutic and the other cultural. Therapeutic rationales presented smoking opium as palliative medicine, a remedy addressed to averting the reputedly lethal effects of sudden opiate withdrawal. It was a medical necessity to supply opium to labourers: 'the Government had been informed that it must be done, there were a certain number of men to whom the drug had become a habit, who could not be stopped from using it at once, without danger to their health.' 97

In their cultural arguments, supporters of the law cast opium as a customary and benign commodity and the practice of its smoking 'near-universal' among the Chinese labouring population, with addiction a greatly exaggerated danger. For example, the colonial secretary declared himself 'not prepared to say that the use of opium in moderate quantities was a serious evil'. ${ }^{98} \mathrm{He}$ had spoken on the matter with people who had lived for a long time in the East, and he had been told that the percentage of those who suffered from an excess of opium consumption was not more noticeable than the percentage of people in the Transvaal colony who suffered from an excessive use of alcoholic use. The secretary to the Mines Department concurred. He suggested that council members were unreasonably frightened by the idea of opium smoking, panicked simply 'by the word "opium". 99 Taken in moderate quantities, he explained, it was well known in the East that it did not cause harm to the individual.

Officials put forth wildly varying accounts of the extent of opium consumption, depending upon whether the justification was medical or cultural. In the former argument, opium was a medicinal necessity for the unbreakable habit of the few. In the cultural argument, opium was a mostly harmless commodity for all, required in the mines because 'it was no use in a week or a month trying to cure 50,000 Chinamen of their ordinary normal habits' ${ }^{\text {Io० }}$ The colonial secretary asked Council members to imagine

if they started to cure 50,000 Europeans of their habits of alcohol, tobacco, or tea drinking, what the result would be? No law that could possibly be passed would cure them. The object of the draft Ordinance was not to prohibit or to licence the use of opium, but to bring the opium traffic under such control as would give some assurance that it was not being abused by the illicit sale of the drug. ${ }^{\text {IOI }}$

The Medical Council sent a memo to Council that was read aloud, explaining the manner in which opium was cooked down and prepared for smoking, and how an amount of ' 2 lbs' decreased through that process. ${ }^{102}$ This information did little to assuage emotion. Council member William Hosken - dynamite and armaments merchant, party Progressive and social liberal-proclaimed that it was now 'quite clear' to him that the Council was

\footnotetext{
97 Ibid, 894 .

98 Ibid. 894 .

99 Ibid. 902.

Io० Ibid. $895^{-6}$.

IOI Ibid, 896.

I02 Ibid. 4 Aug. I906, I019.
} 
'providing large quantities of opium for smoking' while passing it off as a medicine. ${ }^{\text {I03 }}$ Hosken registered his distress that, while the Chinese government toiled to prevent opium use within their own country, an effort that - he reminded the assembly - had occasioned war between Britain and China, his own government 'meekly' accepted whatever the Medical Council and Pharmacy Board saw fit to recommend. 'Every country in the world was today afraid of the spread of the opium habit, and endeavoured to check it. It was only when they came to the Transvaal that they found a change.' ${ }^{\text {ro4 }}$

The secretary to the Mines Department expressed his faith in the expertise of 'medical men', who could be trusted to know the point at which an individual's opium consumption became a problem.

[I]n the East, where they had large numbers of unskilled labourers from China and elsewhere using the drug, there was generally an arrangement by which they were watched by medical advisers and everything that was possible was done to ensure the reduction of the use of the drug whenever it reached that stage[.] $]^{\text {105 }}$

Opposing Council members pointed out the logical implications of the ordinance: 50,000 individuals could legally acquire I००,০০০ pounds weight of opium in a single month. There was nothing preventing them from selling the surplus on to others, including to persons outside the targeted demographic. 'Spread' of the opium habit from Chinese to African labourers and to white civilians was surely inevitable.

Despite objections, on I I September 1906 the governor assented to the Opium Trade Regulation Ordinance. Later that month, a committee made up of the medical officer of health and the colonial secretary, along with a group of pharmacists and physicians with input also from the FLD - finalized details related to the working of the law, including the design and substance of opium application and permit forms. ${ }^{\text {I06 }}$ Government agents distributed these forms - in books of roo - to all mine inspectors.

The Opium Ordinance of 1906 was promulgated during a period of political tensions and electoral transition. Liberal victory in Britain during this year saw a restructuring of government in the Transvaal. Outcries in London resonated - in form if not in kind with local opposition to the Chinese indenture scheme. The issue proved a key factor in Het Volk party victory in the new Transvaal parliament. By the end of 1906, it was clear that the labour 'experiment' would be terminated, a decision the Het Volk cabinet formalized following elections in February I907. Regime changes offered new purchase to anti-opium campaigning, though local public interest in this specific issue remained negligible. ${ }^{\text {I07 }}$

I03 Ibid. I020.

IO4 Ibid. IO2O-I

I05 Ibid. 3 oth July I906, 902.

I06 TAB FLD 23068 , Minutes of meeting 2I Sept. I906 to discuss draft regulation proposed, to be made under the provisions of Ordinance No. 25, I906; Invitation by Assistant Colonial Secretary to FLD Superintendent, I7 Sept. I906; Reply, by same, 20 Sept. (unable to attend but discussion by telephone).

I07 Newspapers carried negative portrayals of opium smoking and opium dens, but there is little evidence that these incited much public alarm. See, for example, 'Yen Yen', Rand Daily Mail (Johannesburg), 23 Nov. I928; 'Opium traffic', Indian Opinion, I8 July I908, 'Vices of the Chinese', Llanga lase Natal, 4 Aug. I905. 
Meanwhile, the new ordinance failed to achieve its stated aims: it neither quelled the high rate of illicit opium circulation, nor effectively brought the market under FLD control. Significantly, by the middle of 1907 , mine inspectors - one after the other - confirmed that not a single application for medical prescription had yet been submitted by a labourer in the manner provided for by the law. ${ }^{\text {I०8 }}$ Instead, medical personnel, chemists and magistrates granted hundreds of prescriptions and permits for medicinal opium to enterprising civilians - notably to 'unindentured Chinese' - who incorporated them into the existing illicit supply chain. ${ }^{\text {I09 }}$ Bureaucratic provision could not address the meanings of opium within the moral, or otherwise coercive, economies of compound life. ${ }^{\text {IIO }}$ Clearly, higher prices, adulterated product, and the legal risks associated with illicit channels of supply were - for a variety of reasons - considered preferable to chemically dependent miners than the prospect of registering themselves with their employers, and being monitored, as addicts.

A further and enormously significant legal development in 1906 was an amendment to the Customs and Tariff Act of I903, legislation to which the Transvaal, Natal, Orange River, and Cape Colonies - as well as the territory of Southern Rhodesia - were signatory. Heads of the customs, treasury, and law departments had pushed for the Act in order to suppress transcolonial smuggling, responsible for the vast bulk of product entering the Transvaal, and to generate revenue from the growth in legitimate consignments. ${ }^{\text {II }}$ Article IX of the Customs Convention prohibited 'the introduction of opium, except for medicinal purposes'. Section 20 of the Customs Amendment and Tariff Law (Act I of I906) outlined the terms under which authorized parties (doctors, dentists and pharmacists) could apply to the colonial secretary's office for importation permits for 'gum opium, extract of opium, poppies and preparation of poppies'. The governor of Natal, claiming to have 'practical experience in the East of the way Chinese get over [that is, manoeuvre around] the word "opium", II ${ }^{2}$ had recommended further categorical specification, inclusive of:

ball opium, the leaves or wrappings in which opium balls have been wrapped, any preparation of opium or of morphine or of any alkaloid of opium, or any preparation in which opium or morphine or alkaloid of opium forms an ingredient which preparation is used or intended to be used for smoking, chewing, swallowing or injecting, dross or refuse of prepared opium which has been used for smoking whether prepared for use or not. ${ }^{\text {II3 }}$

The Customs Act, though without these revisions, passed in June of I906. To the colonial treasurer, Director of Customs J. W. Honey expressed private doubts that any customs law

Io8 TAB LD I4I3 AG/8I3/o7, Commissioner of Police to Law Department, I3 May I907.

I09 Waetjen, 'Transvaal opium trade' (forthcoming).

I IO For example, how white controllers 'purchased the cooperation' of Chinese mine police and indentured labourers through their toleration or otherwise active involvement in the trade. Jamieson notes this dynamic explicitly in his FLD Annual Report I905-6, 9.

I I I Increases are evidenced by applications documented by the Pharmacy Board and handed over to police. See, for example, TAB CS 626/5526, Permits to Import Opium, record submitted by Transvaal Pharmacy Board requested by Commissioner of Police on 27 Apr. I906; Permits to Import Opium, J. H. Dinwoodie to Colonial Secretary, 8 Feb. I906.

I 2 Pietermaritzburg Archives Repository (NAB) NT II4 T2I80/I906, Governor to High Commissioner, 29 June I906.

I 3 NAB NT I I4 T2340/I906, Related by Treasurer to Collector of Customs, Durban, 29 June I906. 
could curtail smuggling and was 'of the opinion that illegal traffic of opium can only effectually be dealt with at the place of consumption and not of import'. II4 However, the passing of the Transvaal Opium Trade Regulation Ordinance (25 of 1906) immediately subsequent to the Customs Act served only to increase demand and the capacities of illicit traders in the compound. ${ }^{\mathrm{II} 5}$

\section{LEGISLATING OPIUM 1909: PREPARING FOR UNION}

In November I906, the British Liberal government ended the Chinese labour scheme and repatriation began. From early 1907, Het Volk politicians and other critics of the opium provision policy sought to align South Africa with emerging global trends. ${ }^{\text {II } 6}$

In May, CMLIA's cultural consultant, G. Baldwin, painted a damning picture of opium use and sales among labourers on the Rand, and called for stringent prohibition. ${ }^{\text {II7 }} \mathrm{He}$ had lived thirty years in China, eight of these supervising 4,000 labourers who comprised 'exactly the class of men whom we work with here, i.e., men from the Chihli and Shantung province'. Further, he had lived 'among them ... not as other Europeans in China are doing, in settlements away from all but their Chinese servants, but in their cities'.

Having this experience I declaim against the sale of opium to any person, whether he be European, Chinese or Negro, as the most baneful thing produced for use of the human being. I have seen innumerable miseries arise through it, worse by far than the effect of [alcoholic] drink. I have seen the dreadful loss of energy it effects, making a good worker into an imbecile. ${ }^{\text {I } 8}$

Baldwin expressed dread that, having imported a workforce from China, South Africa would be repatriating a population of addicts.

Government sought to reduce the monthly maximum from 2 lbs to half a pound. ${ }^{\text {I9 } 9}$ In August, the Druggist and Chemist warned Transvaal pharmacists of the changing mood in London, reporting that 'Lord Elgin has cabled that 2 lbs is too much for a doctor to prescribe for one Chinaman per month and that it must be cut down.' ${ }^{20}$ The FLD, for its part, acknowledged that the I906 Opium Ordinance, created to 'more efficiently' curtail illicit traffic of the drug, had manifestly failed. Instead, 'so far from having obtained the desired object, it has ... resulted in an increase of business of an undesirable nature under quasilegal sanction, and therefore stands selfcondemned' ${ }^{\text {I2I }}$

Anglo-Chinese opium agreements from January 1908, which set out a plan for scheduled cessation of the opium trade, sparked local anti-opium activism. ${ }^{\text {I22 }}$ In May I908,

\footnotetext{
II4 TAB FLD I/I47/2, Director of Customs to Colonial Treasury, 27 Jan. I906.

I 5 Waetjen, 'Transvaal opium trade' (forthcoming).

I 6 TAB FLD 68, Foreign Labour Department Superintendent to Colonial Secretary, I4 June I907.

I 7 KAB MOH 322, Copy 'Opium on the mines of the Witwatersrand'.

I 8 Ibid.

I 9 TAB Gov 1076 37/9/07, Prime Ministers' Office, Minute No. 213, 22 June I907.

I20 Druggist and Chemist, 3 Aug. I907, 206.

I2 I TAB FLD 68, Superintendent to Acting Assistant Colonial Secretary, I 8 May I908. For an account of how the permit system was incorporated into illicit networks, see Waetjen, 'Transvaal opium trade' (forthcoming).

I22 The so-called 'ten percent solution' had local consequences in many regions. See, for example, Boyd, 'Canadian narcotics legislation', I IO-I 2.
} 
resident Chinese community leaders, with support from the Witwatersrand Church Council, petitioned for the criminalization of opium smoking as a practice, extending to a ban on opium pipes and related paraphernalia. ${ }^{\mathrm{I} 23}$ The Chinese Consul-General for the Transvaal, Lin Ngai, took up this request and rallied, also in the coastal colonies, for stringent legislation. ${ }^{\text {I24 }}$ The Cape Colony went as far as drafting a bill, modelled explicitly after the 1895 bans in Australia and Tasmania but, almost as quickly, dismissed it as an expensive and impractical measure, relevant only to a diminutive opium-smoking population. ${ }^{\mathrm{I} 25}$ The FLD protested against any further reforms, arguing that 'the number of unindentured Chinese residents probably amounts to less than I200' and that repatriation, rapidly depleting the indentured population, would resolve the crisis. ${ }^{\mathrm{I} 26} \mathrm{R}$. J. Purdon, last superintendent of the FLD, put his faith in the demographic containment of workers and the excluded status of Chinese residents. In his view, reports that opium smoking was 'spreading' to other groups were unfounded. He was 'not aware of any aboriginal native of South Africa having been convicted under [any opium] ordinance'. Meanwhile, he was satisfied that 'Chinese detectives bring indentured Chinese to book for illicit trade.' ${ }^{27}$

The Transvaal Pharmacy Board actively lobbied against reducing the existing monthly maximum of smoking opium that could be bought through medical prescription, arguing that this would further stimulate smuggling and informal profiteering. ${ }^{28}$ Chamber of Mines chairman, George Craik, now pointed fingers at the medical fraternity. ${ }^{\mathrm{I} 9}$ As he saw things, the 1904 Pharmacy Ordinance had declared opium a poison but not prevented 'any chemist from selling as much as he pleases and these provisions were found to be totally inadequate to prevent large quantities of opium coming into the hands of hawkers and other unauthorized persons who retailed it illegally among the coolies'. He 'would have been' supportive of a prohibition earlier but proclaimed it was now too late. With levels of addiction rampant, he could not support further restrictions because there existed 'certain medical evidence to show that this might have a fatal effect on men, whether indentured coolies or others who had already acquired the opium habit'.

It was not until February I909, with British delegates sitting at the Shanghai Opium Commission and under pressure also from American and Chinese representations, that Transvaal lawmakers began to move towards reform. ${ }^{130}$ With South Africa's epidemic officially attributed to the presence of foreigners, whose removal would constitute a solution, the key issues to be addressed were political. Officially, the issue was about contagion

I23 TAB FLD 230 68/52, Petition, Chinese Association of Johannesburg to Chinese Consul-General, I 5 May I908.

I24 TAB FLD, Chinese Consul-General to Governor Selbourne, I 5 June I908; KAB T Part I 986 4I5/O8, Correspondence between Acting Imperial Chinese Consul General, Lin Ngai and Prime Minister Cape Colony, I July I908. Additional petitioning followed on I2 Aug. I908 and 25 Aug. I908.

I 25 KAB T Part I 986 I35/492, Report by AG to Prime Minister concerning possible legislation proposed by the Chinese Consul General, 8 Aug. I908; KAB T Part I 986 23/I63, Gregory to Advocate Morgan Evans, Attorney General's Office, 20 July I908.

I 26 TAB FLD 230 68/52, Purdon to Law Department, 4 Sept. I908.

I 27 Ibid.

I 8 TAB FLD 68, Secretary of the Transvaal Pharmacy Board to Assistant Colonial Secretary, 8 June I907.

I 29 TAB FLD 230 68/52, Craik to Law Department, I 5 May I 908.

I30 TAB BBB г 82 CD 4898 Part I, 'International Opium Commission at Shanghae, I909', Sir Edward Grey to the British Delegates to the International Opium Commission of Shanghae, 625. 
and racial boundaries, anxieties repeatedly expressed as a 'spread of the opium habit'. ${ }^{\text {I3 I }}$ Colonial Secretary J. C. Smuts, with a decade-long track record of energetic intolerance for interracial mixing in the criminal underworld, was poised to act on the police commissioner's qualified assessment in March that 'the opium habit has undoubtedly spread to both Europeans and Natives in the Transvaal, and to the Cape Coloured people but fortunately not on a large scale'. ${ }^{{ }^{2} 2}$ On 4 May I909, CID escorted Law Department Secretary Jacob de Villiers Roos on a brief tour of opium dens in Ferreirastown and the rickshaw yards of hawkers near Doornfontein. His evident disgust at the apparent intersociality of 'American Jews', 'bastard' women, 'Kaffirs and Coolies' that he encountered in these spaces added weight to Smuts's, and other political allies', push for reform on grounds of race nationalism. ${ }^{\mathrm{I} 33}$ In mid-May, Smuts informed the Chamber of Mines that, although he would not proceed without their input, there existed 'very strong representation' against the Transvaal Opium law of 1906, which 'assists in the maintenance of opium dens and opium smoking generally as men are able by pooling the opium purchased under authority of authorized permits to supply the requirements of an opium den and thus through the medium of the law are carrying on an undesirable business.'

When on II June I909, Smuts introduced the new opium bill to the Transvaal Legislative Council he described it as 'very urgently called for'. 'Vices', he explained, were

springing up in the Transvaal which we ought to cope with at the earliest opportunity. Members of this House who have taken the trouble to visit the opium dens in Johannesburg know the extent of the vice. There they have found not only Chinese, but coloured people and even natives, in fairly large numbers ... I have seen the necessity for a drastic alteration of the law; and it is now proposed that there should be an entirely different machinery for the control of the trade in opium. ${ }^{\mathrm{I} 34}$

The Opium Trade Regulation Amendment Bill of I909 repealed Section 8 of the I906 Act. Allegedly to prevent the most disastrous effects of withdrawal amongst addicts, it continued provision of smoking opium by medical certification to persons who had 'acquired the habit ... prior to that date' but reduced the monthly maximum from 2 lbs to four ounces. Provision would be terminated entirely 'six months immediately succeeding the date of promulgation of this Gazette but not afterwards'. ${ }^{35}$ Smuts explained that 'during that time of grace inveterate smokers must become cured of their evil habits.' Further,

If they do not become cured - and I do not expect that they will become cured - they will probably leave the country, and the sooner they leave the better. (Hear, hear.) We have, owing to our legislation, been collecting opium smokers not only from our own country, but from other parts of the world and the evil must be drastically coped [sic] with. ${ }^{\mathrm{I} 36}$

\footnotetext{
I3 I See KAB T Part I 986, Correspondence between Acting Imperial Chinese Consul General, Lin Ngai and Prime Minister Cape Colony, I July I908, I2 Aug. I908, and 25 Aug. I908.

I32 TAB CS 883, RB Begg to Assistant Colonial Secretary, Io Mar. I909.

I33 L. Chisholm, 'Crime, class and nationalism: the criminology of Jacob de Villiers Roos, r869-I9r 8', Social Dynamics, 3:2 (I987), 46 and 49-50.

I34 Legislative Debates, I I June I909; I I June I909, 244.

I35 Transvaal Original Annexures to the Votes and Proceedings of the Legislative Assembly, Volume III (I909) Opium Trade Regulation Amendment Ordinance, Section I (2), I.

I36 Legislative Debates, I I June I909, 245.
} 
B. O. Jones of Boksburg West, a pharmacist, supported the bill, convinced that 'the time had arrived' because there was 'no necessity for its importation now, as there was previously'. Without any evident irony, he proclaimed it 'high time that something was done to stamp out this evil, which was a very crying evil in our midst'. ${ }^{137}$

The law was passed at the end of June I909. The following year opium provision ended as the last indentured Chinese migrants departed from Port Natal. The labour intensive gold industry had relied on Chinese migrants to re-establish the economy following the South African war. While they were present on the Witwatersrand, mine companies, state legislators, and organized medicine and pharmacy had been eager to benefit from the drug economy that had formed on the Rand. In the decades that followed, into the I920s when national laws were promoted under pressure of the League of Nation's Dangerous Drugs committees, the Witwatersrand episode was all but forgotten.

\section{CONCLUSION}

The case of opium addiction in the compounds of the Witwatersand gold mines between I904-IO, under conditions of unfreedom and confinement, confirms some of the key elements of a medical regime that McCulloch has sought to expose through the case of silicosis. ${ }^{138}$ Specifically, it evidences mine medicine as complicit in concealing the scale and nature of an occupational malady from public scrutiny, in promoting diagnoses based on racial orthodoxies and in employing repatriation as a valve for excising ill bodies. Yet medical provision of smoking opium to indentured Chinese migrants through the FLD bureaucracy represents a singular development.

The critical point to be made here is that treatment of opiate-addicted men in this context was, in fact, nothing more or less than the chemical management of their labour power. It was an industrial therapy, formulated through a confluence of medical and penal regulations and institutions, to maintain the work-fitness of ailing bodies. As a form of somatic control, moreover, it further demarcated a racial and criminal basis of their alienation and exceptional political status. Fetishized in official language as an 'evil', attributed to various 'undesirables' and to workers themselves, opium confronted colonial administrators and mine owners as both a challenge and a remedy in struggles of nation and class.

While it is impossible to calculate the extent to which drug provision contributed to labour productivity and pacification after 1906, it is significant that the received understanding of these events among administrators around the unifying territories was that ' $[t]$ he Transvaal tried to stop the Chinese from smoking but found they did not work as well without opium. ${ }^{\text {I } 39}$ It is clear enough that the mining industry and organized pharmacy viewed opium provision as a joint venture for mineral and chemical profits.

I37 Ibid. 246-7.

I3 8 McCulloch, 'Mine medicine', 422 and 425-430.

I39 KAB MOH 322 Gis7b, Medical Officer of Health of the Cape Colony, explaining opium on the Witwatersrand in an interview of the representatives of the Cape Pharmaceutical Society, 29 July I907. 
At first glance, however, state sponsored narcotic supply appears a departure from the momentum of industrial reform through which imperial progressives and modern statebuilders sought to rationalize health and worker discipline on the mines, most crucially though among other measures - through prohibitions and policing around alcohol. This would seem to present a puzzle for historians of modern state-making who, like Patrick Harries, view the laws of the late 1890 s as locking in regulatory controls over labour at the behest of mining capital. ${ }^{\mathrm{I}}{ }^{\circ}$ Does the case of opium represent a retrogressive lapse, or otherwise return, to a policy that, within Kruger's Republic, had married the interests of emergent narcotic capital with strategies of worker recruitment, appeasement and control? Were the 1906 compromises around opium a reflection of renewed official tolerance for the circulation of intoxicants? To what extent does this story present an anomaly in Milnerian strategy?

To consider these questions, the nature of opium law-making and ongoing consultation with medical expertise should, in some measure, be assessed in the light of the peculiar properties and ambiguities of opium as a substance. It is significant that in the Transvaal (and not, for example, in the Cape Colony) the 'medicinal purposes' of opium ingestion were extended to the practice of smoking and that industrial drug provision was framed in terms of worker health and vitality. ${ }^{\mathrm{I}}{ }^{\mathrm{I}}$ Circulating ideas about the lethal effects of opiate withdrawal, the clinching rationale for drug maintenance on the Rand, sanctioned the political intervention of doctors and pharmacists.

Opium differed from alcohol as an exotic commodity that could not be manufactured locally and, indeed, required the mobilizing of transoceanic trading networks. As a substance both potent and lucrative in small sizes, opium lent itself to undetectable (or else easily overlooked) transport. Thus, the financial stakes of Transvaal chemists in cornering opium sales rested entirely on control of imports (rather than local cultivation and manufacture as was the case with alcohol) but with poor prospects for defeating illicit competition. Although it is clear that pharmacists certainly profited, both financially and politically, during these years, their numbers were too small and their occupation too specialized to be attributed (as liquor manufacturers had once been) with interests aligned to a national economic good. Indeed, it was rather the claim to scientific knowledge, by medical and chemical professionals, about addiction and about opium itself that, in a climate that valorized progressive, modern state-making, leveraged their position as the official gatekeepers of opium permissions and as legitimate suppliers. In turn, it was the involvement of such experts that allowed the state - to the extent it proved expedient - to frame their policy as medically and scientifically rational.

That particular type of rationality was not oriented towards biomedical universals but was racist and expulsory. It was invested in the legal construction of a 'special biochemical zone', corresponding to the carceral conditions, exceptional legal status and temporary residency of bonded Chinese labourers. Confinement was the crucial enabling feature both of the developing opium trade and of governmental attempts to medicalize and

\footnotetext{
I40 Harries, Work, Culture, Identity, 228; I35-7, I90, and 227-228.

I4 I See Waetjen, 'Drug dealing doctors'. In the Cape, physicians faced disciplinary charges of unprofessional and disgraceful conduct for prescribing smoking opium to chemically dependent individuals.
} 
financially benefit from it. The idea that opium smoking was quintessentially a Chinese practice assisted the logic of biochemical zoning: Chinese bodies, bearers of alien culture and exceptional class relations, might incubate a 'habit' that could be accommodated in uncivil spaces. Yet, recognition that any human being could smoke opium made the notion of 'spread' intelligible within the racial politics of white public crisis. Contagion became the official rationale for opium's recriminalization.

Gary Kynoch has argued that '[a]lthough it seems to have been rampant, opium use did not arouse much official interest.' ${ }^{\mathrm{I} 42}$ An erratic trail of legislation and lobbying indicates that official interest was, in fact, intensive. Yet Kynoch's broader point - that concern was determined by mining productivity and labour control - is certainly supported here in this study. Law-makers and their medical allies accommodated the requirements of mining capital until, after most indentured migrants had returned to China, the state conceded symbolic ground to global trends.

I42 Kynoch, 'Your petitioners', 535 . 